\title{
Pollinator Refuge Establishment and Conservation Value: Impacts of Seedbed Preparations, Seed Mixtures, and Herbicides
}

\author{
Gina M. Angelella, Laura Stange, Holly L. Scoggins, \\ and Megan E. O'Rourke ${ }^{1}$ \\ School of Plant and Environmental Sciences, Virginia Tech, 185 Ag-Quad \\ Ln, Blacksburg, VA 24061
}

Additional index words. wildflower, no till, imazapic, graminicide, sethoxydim, perennial, pollinator

\begin{abstract}
On-farm pollinator refuge habitats can supplement floral and nesting resources to support wild and managed pollinator communities. Although the popularity of installing these habitats has grown, and federal programs provide technical and financial advice to participating landowners, recommendations regarding habitat establishment and species composition vary. We examined the effects of seedbed preparation, seed mix composition, and herbicide applications on pollinator refuge establishment and pollinator visitation in a controlled experiment across 2 years. Seedbeds were prepared either by a no-till method with glyphosate herbicide or by repeated conventional inversion tillage. Seed mixes contained either nine annual, biennial, and perennial forbs (mix AP); seven annual, biennial, and perennial forbs that are tolerant to imazapic herbicide (mix IT); or nine perennial forbs (mix $P$ ). Mixes $A P$ and $P$ were grown with and without application of the graminicide herbicide sethoxydim and mix IT was grown with application of the herbicide imazapic. Seedbed preparation methodology had a strong impact on pollinator refuge establishment. A no-till approach generated greater wildflower and lower weed cover relative to tillage, leading to a greater number of blooms. In particular, there were more Indian blanket, purple coneflower, slender mountain mint, and wild bergamot blooms following a no-till seedbed preparation, indicating that certain species are more vulnerable to the effects of tillage than others. The AP and IT treatments displayed more wildflower and less weed percent cover than the $P$ treatments during the first year, but in the second year wildflower and weed cover were similar across all mixes grown with and without herbicide. Overall pollinator abundance, which was dominated by native bees, correlated positively with wildflower bloom counts, suggesting that habitat establishment methods that increase wildflower blooms can positively affect the pollinator conservation value of the habitats. This research indicates that establishing on-farm wildflower habitats can be most successful with no-till seedbed preparation, a mixture of annual, biennial, and perennial forb species, and that herbicides applied after planting wildflowers may not be worth the costs of application.
\end{abstract}

Habitat installations rich in floral pollen, nectar, and nesting resources can support local pollinator populations on farms, thus providing a farmscaping tool to alleviate native and managed pollinator declines and the accompanying declines in pollination ecosystem services (Vaughan and Skinner, 2008, 2015). Pollinator habitat installation is supported by federal programs such as the Environmental Quality Incentives Program and the Conservation Reserve Program, through which technical and financial assistance is provided to

\footnotetext{
Received for publication 24 Sept. 2018. Accepted for publication $18 \mathrm{Dec} .2018$.

We thank Velva Groover, Chris McCullough, and Mike Graham for data collection contributions. This research was supported by USDA Agroecosystem Management Grant 11664133 and start-up funds provided to M.E. O'Rourke by the College of Agriculture and Life Sciences at Virginia Tech. ${ }^{1}$ Corresponding author. E-mail: megorust@vt.edu.
}

participating farmers by, respectively, the U.S. Department of Agriculture's Natural Resources Conservation Service (USDA NRCS) and the Farm Service Agency (Vaughan and Skinner, 2008, 2015). Pollinator refuge habitats (PRs) in these programs are designed to provide blooms throughout the entire growing season and may also contain grasses depending on regional recommendations (FSA, 2013). As interest in these programs develops, there have been calls for research into the factors affecting PR establishment and effectiveness. Specifically, how can wildflower establishment success be maximized to obtain the full diversity of the mix planted (Williams et al., 2015)? Furthermore, how does PR establishment success and species composition affect pollinator communities (Venturini et al., 2017)? We conducted a study to address these questions, investigating PR establishment and pollinator conservation value relative to seedbed preparation, seed mix composition, and herbicide treatments.
Seedbed preparation is one of the most important actions affecting PR establishment success because of its long-term impacts on weed management (Aldrich, 2002; Martin, 1986; Wilson, 1992). Previous studies indicate that weed competition can be a critical factor limiting PR success (Aldrich, 2002; Howell and Kline, 1992; Norcini and Aldrich, 2004; Perry, 2005). Although seedbed preparation recommendations for PR installations vary (NRCS, 2007, 2012; Vaughan et al., 2013), a review of the literature suggested repeated tilling, herbicide applications, or both are better methods for perennial weed management than other strategies such as grazing, solarization, or burning (Aldrich, 2002). Studies comparing the results of a no-till/ preemergent herbicide method with repeated tillage have yielded conflicting results (Ahern et al., 1992; Corley, 1991; Corley et al., 1993; Skousen and Venable, 2008), but a recent study showed that in the first establishment year, a mixture of annual, biennial, and perennial wildflowers planted on cropland is more successful in a no-till than a tilled system (Angelella and O'Rourke, 2017).

After preparing a PR seedbed, a critical question is which species of wildflowers to plant. Pollinator habitat mix composition may affect both wildflower and weed establishment as well as pollinator conservation. Annual wildflowers can reduce weed competition during the critical initial phases of establishment (Aldrich, 2002) and can provide floral resources in the first year, but species should be selected so as to minimize the risk of becoming weeds themselves if seeds get dispersed outside PRs (Menz et al., 2011). The benefits of perennial wildflowers include that they compete well with annual weed species once they are established (Lulow, 2006) and that they do not require frequent overseeding (Aldrich, 2002). Moreover, some research suggests bumblebees and butterflies prefer perennials over annuals (Feber and Smith, 1995; Fussell and Corbet, 1992), although other studies report a lack of preference (Carreck et al., 1999), or that a combination of annuals and perennials can work complementarily to attract more pollinators (Williams et al., 2015). Although PRs will certainly be influenced by the species-specific preferences of growers, more can be done to develop general recommendations about the benefits and trade-offs of species mixes that consist of all perennials or a combination of short- and longlived species.

Managing weeds after planting wildflowers is another major challenge that growers and advisors must address during the PR establishment process. Some studies indicate that herbicides improve PR establishment, whereas others indicate that it is an unnecessary expense. The selective herbicide imazapic, for example, can enhance the establishment of tolerant wildflower species (Beran et al., 1999), but effects can vary by site and species (Frances, 2008) as well as by weather conditions, soil quality, and seed source (Norcini and Aldrich, 2004). Similarly, the 
graminicide sethoxydim enhanced wildflower establishment and richness in two studies (Hitchmough et al., 2008; Trowbridge et al., 2017), but was found to be ineffective in another (Frances, 2008). Further investigation into the consistency of herbicide effectiveness applied during the early stages of PR growth would enhance our ability to make recommendations regarding weed management practices for successful PR establishment.

To address questions of how to best establish PRs on cropland and the subsequent impacts on pollinators, we examined the effects of seedbed preparation, seed mix composition, and herbicide use on PR establishment in a controlled field experiment over two years. We hypothesized that 1) wildflower establishment would be higher and weed establishment would be lower following a no-till than a tillage seedbed preparation; 2) herbicide applications following PR planting would suppress weeds and enhance wildflower growth; 3 ) mixes containing both annuals and perennials would have more wildflower growth, more bloom coverage, and less weed growth than a mix containing only perennials; and 4) pollinator abundance would correlate positively to bloom density.

\section{Materials and Methods}

Experimental design. We established experimental sites at the Virginia Tech Kentland Agricultural Research Farm, in Montgomery Co., VA (lat. $37^{\circ} 11^{\prime} 59118^{\prime \prime} \mathrm{N}$, long. $\left.80^{\circ} 33^{\prime} 51.8688^{\prime \prime} \mathrm{W}\right)$. The farm is in the USDA Plant Hardiness Zone 6b, and the experimental site was on fine-loamy, mixed, active Ultic Hapludalf soil. The fall before our study, the experimental site had been planted with annual rye (Lolium multiflorum Lam.) and hairy vetch (Vicia villosa Roth) cover. The experiment was designed as a randomized complete block experiment with four replicate blocks and 10 experimental treatment plots per block. Each plot measured $6.10 \times 2.74 \mathrm{~m}$. The plots consisted of a combination of seedbed preparation, seed mixes, and herbicide treatments in an unbalanced factorial design. Specifically, we tested the effects of seedbed preparation (till and no till) fully crossed with three wildflower species mixes: an annual and perennial mix (mix AP), an imazapic-tolerant mix (mix IT), and a perennial-only mix (mix P). We also examined the effects of herbicide treatments, but they were not fully crossed with the other treatment factors because herbicide management was specific to the wildflower mix. Mix AP was tested with (treatment AP-h) and without graminicide (treatment AP), mix IT was tested just with imazapic (treatment IT), and mix $\mathrm{P}$ was tested with (treatment $\mathrm{P}-\mathrm{h}$ ) and without graminicide (treatment $\mathrm{P}$ ).

To prepare seedbeds before planting, we applied glyphosate to no-till plots at $4.68 \mathrm{~L} \cdot \mathrm{ha}^{-1}$ using a tractor-mounted 6.1-m boom sprayer (Reddick, Williamston, NC) on 13 Apr. and 26 Apr. 2016. Concordantly, we rotary powertilled (Kuhn EL 43-190; Broadhead, WI) tillage plots on 13 Apr. 2016, making two passes with the tiller down the plots. All plots were packed with a homemade roller $(\approx 132$-cm-long barrel holding $378.5 \mathrm{~L}$ water) pulled by a tractor immediately pre- and postplanting to ensure good seed to soil contact. Seed mixes were developed with USDA NRCS technical advice (B. Glennon, personal communication) for native or naturalized species appropriate for Virginia that would provide bloom coverage from late spring through late summer. One mix (mix AP) contained annual [partridge peaChamaecrista fasciculata (Michx.) Greene, plains coreopsis-Coreopsis tinctoria Nutt., and indian blanket-Gaillardia pulchella Foug.], annual or biennial (blackeyed SusanRudbeckia hirta L.), and perennial forbs [lanceleaf coreopsis-Coreopsis lanceolata L., purple coneflower-Echinacea purpurea (L.) Moench, maximilian sunflower-Helianthus maximiliani Schrad., wild bergamot-Monarda fistulosa L., and narrowleaf mountain mintPycnanthemum tenuifolium Schrad.]; a second mix (mix IP) consisted of an imazapic-tolerant subset of mix AP (C. fasciculata, C. tinctoria, G. pulchella, R. hirta, C. lanceolata, E. purpurea, and $H$. maximiliani); and a third mix (mix P) contained only perennial forbs, including all the perennials in mix AP and four additional perennial species [pale purple coneflower-Echinacea pallida (Nutt.) Nutt., spotted bee balm-Monarda punctata L., showy evening primrose-Oenothera speciosa Nutt., and tall white beardtongue-Penstemon digitalis Nutt. ex Sims] (Supplemental Table 1). For bulking purposes, we mixed seeds in a 20:1 pelletized lime (Soil Doctor, Haines City, FL) by seed weight ratio, at a rate of 30-140 seeds/ $\mathrm{m}^{2}$ and hand-broadcast them in treatment plots on 26 Apr. 2016. Treatments AP-h and P-h were sprayed with the grass-selective, broadspectrum, postemergent herbicide sethoxydim at $1.17 \mathrm{~L} \cdot \mathrm{ha}^{-1}$ on 18 July 2016. Mix IT, containing imazapic-tolerant species only, was sprayed with a postemergent treatment of imazapic at $0.29 \mathrm{~L} \cdot \mathrm{ha}^{-1}$ during the first year of establishment on 18 July 2016; imazapic was also applied as a pre-emergent herbicide during the second year of the study on 8 May 2017. Sethoxydim and imazapic treatments were applied with a backpack sprayer (Solo, Newport News, VA). Vegetation was mowed in an effort to control weeds in the P and P-h plots on 12 July and 8 Aug. 2016 to a height of $10 \mathrm{~cm}$ with a rotary mower (Woods 121; Oregon, IL). Vegetation within all plots was mown to 30.5 $\mathrm{cm}$ with the Woods rotary mower after wildflower senescence on 16 Sept. 2016 and again on 31 Oct. 2016. All plots were mown only one time at the end of the growing season in 2017 on 4 Oct. to a height of $30.5 \mathrm{~cm}$ with the Woods rotary mower.

Wildflowers and weeds. Within the PR treatments, we quantified wildflower and weed biomass and percent cover, and numbers of wildflower blooms during the first (2016) and second (2017) years of establishment. We recorded total wildflower and total weed percent cover per square meter by taking two random subsamples per plot three times in 2016 (13 June, 20 July, and 8 Sept.) and three times in 2017 (6 June, 25 July, and 11 Sept.); total grass percent cover was quantified similarly only on 8 Sept. 2016 and on 11 Sept. 2017. We also counted total blooming plants per wildflower species at three time points in the first year (13 June, 20 July, and 8 Sept. 2016) and total number of blooms at eight time points in the second year (24 May, 13 June, 28 June, 18 July, 31 July, 14 Aug., 28 Aug., and 27 Sept. 2017) within two randomly dropped square meter quadrants per plot. To quantify the number of blooms in the second year, the number of individual stems with open inflorescences on them was tallied. Composites and umbels were considered one flower; e.g., lanceleaf coreopsis with multiple blooming branches off of a stem were individually counted, whereas multiple blooms on an unbranched stem such as partridge pea or maximilian sunflower were counted as one.

Pollinators. We recorded pollinator abundance and floral visitations through visual observations during 2017. We divided pollinators into the following categories: honey bees (Apis mellifera L.), bumblebees (Bombus spp.), other bee species (Apiaceae, excluding Bombus spp. and A. mellifera), syrphid flies (Syrphidae), wasps (insects within the suborder Apocrita), and butterflies and moths (insects within the order Lepidoptera). Pollinator observations were made in the mornings after dew was dry on seven dates throughout the second year roughly coinciding with bloom counts (9 June, 22 June, 6 July, 18 July, 2 Aug., 16 Aug., and 30 Aug. 2017). Floral visitations - that is, the wildflower species on which each pollinator landed - were additionally recorded on the three observation dates in Aug. 2017. Pollinator observations were conducted by dividing each plot in half and observing all pollinators interacting with flowers for three minutes in each half of the plot. Care was taken to not count the same individual pollinator twice within a particular plot-half. Plots were observed in random order on each sampling date.

Data analysis. We examined the effects of seedbed preparation and mix-herbicide treatments on total wildflower cover, total weed cover, grass weed cover, total wildflower blooms, and numbers of individual species' blooms. Each of these factors was analyzed by fitting fully factorial generalized linear mixed models to the data, with seedbed preparation as a fixed effect, the five mixherbicide treatments as a second fixed effect (i.e., treatments AP, AP-h, IT, P, and P-h), an interaction between seedbed preparation and mix-herbicide treatments, and block as a random effect. Analyses were conducted for each year of study. Data were averaged over plot subsamples and sample dates within years before analyses. Total wildflower cover was cube-root transformed for both years of data, total weed cover was arcsine squareroot transformed for 2016 data, percent grass cover was $\log +1$ transformed for 2017 data, and total wildflower blooms were log transformed for both 2016 and 2017 data before analysis to meet model assumptions of 
normality and homogeneity of variance. Because of scarcity, slender mountain mint and indian blanket bloom counts from the second year were converted to presence/absence data and analyzed with binomial regression and a logit link. Bloom count data for perennial species were not analyzed in the first year because they were not yet blooming. We performed Tukey's honestly significant difference (HSD) tests of sample means when model factors were significant at the 0.05 level, and there were more than two levels for the factor.

Pollinator data were analyzed to examine relationships between total blooms and total pollinator abundance, treatments and total pollinator abundance, and specific species' blooms and specific pollinator groups. To examine the relationships between total wildflower abundance and total pollinator abundance, we averaged wildflower bloom and pollinator abundance data across all sample dates in 2017 and conducted a linear regression with mean total pollinator observations per square meter as the response variable and total wildflower blooms per square meter as the predictor variable, with herbicide-mix as a blocking factor. To evaluate the effects of the experimental treatments on pollinators, total pollinator abundance was averaged over sampling dates, log transformed, and analyzed with generalized linear mixed models, in which herbicide-mix and seedbed preparation and their interaction were fixed effects and block was a random factor. To identify variations in floral visitation across pollinator groups, we first divided the total pollinator data into five categories: honey bees ( $A$. mellifera), bumblebees (Bombus spp.), moths and butterflies (lepidopteran spp.), wasps (narrow-waisted Apocrita spp.), "other bees" (all other hymenopteran spp.), and syrphid flies (Syrphidae spp.). Only wildflower species visited by at least one pollinator per block were analyzed. Pollinator visitations were averaged over the 3 Aug. 2017 sample dates, and simple analyses of variance with pollinator group as a fixed effect and block as a random factor were used to test the differences in pollinator visitations among pollinator groups for each flower species. Tukey's HSD tests were used in pollinator analyses to assess significant differences among treatment groups.

\section{Results}

Wildflowers. Total wildflower percent cover increased over the 2 years of study, with an average across all treatments and sampling dates of $9 \%$ in 2016 and $49 \%$ in 2017. Total wildflower cover was significantly affected by the mix-herbicide treatment and seedbed preparation in both the first year [mix: $F_{(4,27)}=33.70, P<0.0001$; seedbed preparation: $F_{(1,27)}=62.00, P<$ $0.0001]$ and the second year [mix: $F_{(4,27)}=$ $2.81, P=0.045$; seedbed preparation: $F_{(1,27)}=$ $12.68, P<0.0014]$. In the first year, wildflower cover was greater in treatments containing annuals, biennials, and perennials
(AP, AP-h, and IT) than in treatments containing perennials only ( $\mathrm{P}$ and $\mathrm{P}-\mathrm{h}$ ) (Fig. 1). This changed in the second year in that, although the mix-herbicide treatment effect was significant overall, differences in wildflower cover between particular mixes were not statistically different by Tukey's HSD post hoc analysis (Fig. 1). Wildflower cover was consistently greater following the no-till method than the tillage method in both years (Fig. 2).

Only the plots with annual species bloomed during the first year, whereas all wildflower plots bloomed during the second year (Table 1). Black-eyed Susan provided the greatest bloom counts overall, followed by indian blanket, partridge pea, and plains coreopsis. Two species in the perennial-only mix, pale purple coneflower and tall white beardtongue, never bloomed during the 2 years of study (Table 1). Three of the four annuals and biennials increased in blooms in the second year relative to the first: blackeyed Susan $\left[\chi_{(1,48)}^{2}=31.50, P<0.0001\right]$, plains coreopsis $\left[\chi_{(1,48)}^{2}=5.34, P=0.021\right]$, and partridge pea $\left[\chi^{2}(1,48)=35.31, P<\right.$ 0.0001] (Table 1). Bloom counts peaked at the mid-July sample dates in both years for treatments AP, AP-h, and IT. The perennialonly treatments ( $\mathrm{P}$ and $\mathrm{P}-\mathrm{h}$ ) peaked in September in the second year driven by spotted bee balm blossoms.

Although there were no treatment effects on total wildflower blooms during the first year, in the second year total wildflower blooms were affected by $\operatorname{mix}\left[F_{(4,27)}=\right.$ 21.55, $P<0.0001]$ and seedbed preparation $\left[F_{(1,27)}=4.93, P=0.035\right]$. In 2017, mixes AP-h and AP had the largest, mix IT was intermediate, and mixes $\mathrm{P}-\mathrm{h}$ and $\mathrm{P}$ had the smallest bloom counts. Bloom counts were larger overall following a no-till preparation than a tillage preparation (Supplemental Fig. 1). Individual wildflower species were also affected by seedbed preparation with more indian blanket in the first $\left[\chi_{(1,24)}^{2}=\right.$ 9.22, $P=0.0024]$ and second $\left[\chi_{(1,24)}^{2}=4.37\right.$, $P=0.037]$ years, and more purple coneflower $\left[\chi_{(1,24)}^{2}=19.26, P<0.0001\right]$, slender mountain mint $\left[\chi_{(1,24)}^{2}=11.60, P=0.0007\right]$, and wild bergamot $\left[\chi_{(1,24)}^{2}=4.78, P=0.029\right]$ in the second year in plots with no-till than tillage seedbed preparation (Supplemental Table 2).

Weeds. Total weed cover decreased over the 2 years of study, with large concomitant shifts in the weed communities. In the first year, grasses dominated the weed community and averaged $89 \%$ cover by September across all the treatments. However, by the end of the second year, the weed community had shifted toward more broadleaf species such that broadleaf weeds made up 55\% and grasses made up $15 \%$ of the cover, on average (Supplemental Fig. 2). The primary weed in the first year was large crabgrass [Digitaria sanguinalis (L.) Scop.] with additional patchy outbreaks of hairy galinsoga (Galinsoga quadriradiata Cav.). In the second year, the major weeds were smartweed (Polygonum pensylvanicum L.), clover (Trifolium sp.), and

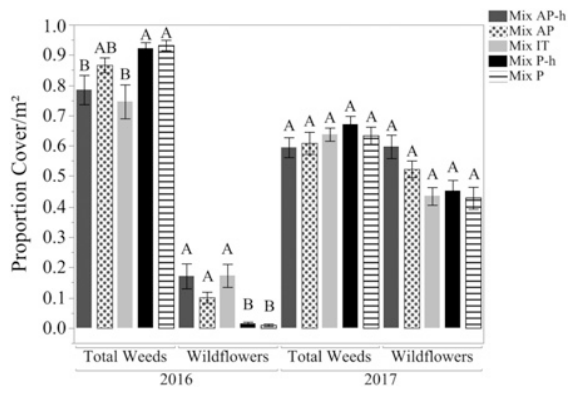

Fig. 1. Proportions of wildflower and total weed cover by mix in 2016 and 2017. Annual and perennial mix (mix AP-h) includes nine species of annual and perennial wildflowers and was treated with a sethoxydim herbicide, mix AP is the same wildflower mix without herbicide, imazapic-tolerant mix (mix IT) contains a subset of seven AP wildflower species and was treated with imazapic herbicide, perennial-only mix (mix P-h) contains nine perennial wildflowers and was treated with sethoxydim herbicide, and mix $\mathrm{P}$ is the same wildflower mix without herbicide. Tukey's honestly significant difference tests were performed to evaluate significant differences at the $P \leq 0.05$ level.

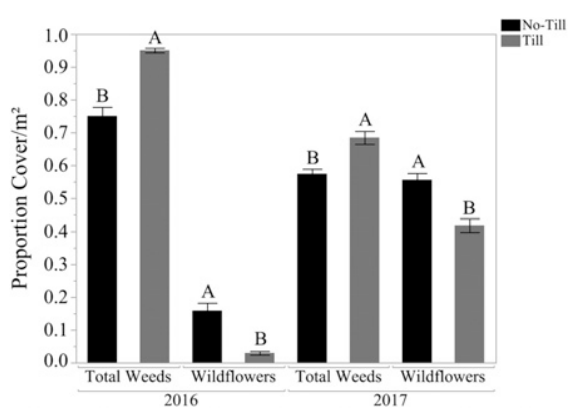

Fig. 2. Proportions of wildflower and weed cover by no-till and till seedbed preparations in 2016 and 2017. Tukey's honestly significant difference tests were performed to evaluate significant differences at the $P \leq 0.05$ level.

chickweed (Cerastium sp.). Total weed cover was significantly affected by mix-herbicide treatment in $2016\left[F_{(4,27)}=12.26, P<0.0001\right]$ and was greater in the first year in the perennial ( $\mathrm{P}$ and $\mathrm{P}-\mathrm{h})$ treatments than treatments with annuals, biennials, and perennials (AP, AP-h, and IT). However, there were no differences in weed cover among mixherbicide treatments in the second year (Fig. 1). The effects of seedbed preparation on weed cover were similar in both years, with the total weed cover being lower following a no-till preparation than a tillage preparation across all mix-herbicide treatments [2016: $F_{(1,27)}=$ 100.23, $P<0.0001 ; 2017: F_{(1,27)}=9.58, P=$ 0.0045] (Fig. 2).

Pollinators. Pollinators were more abundant in treatment plots with more blooms (Fig. 3). Their abundances also varied by mix-herbicide treatment (but not seedbed preparation) with significantly more pollinators sampled in the AP-h and AP treatments than the $\mathrm{P}$ treatment $\left[F_{(4,30)}=5.62, P=\right.$ 0.0017; Fig. 4]. Honey bees were observed 
Table 1. Mean overall bloom counts $/ \mathrm{m}^{2}$, bloom period, and peak bloom time for each wildflower species.

\begin{tabular}{|c|c|c|c|c|c|c|c|}
\hline \multirow[b]{2}{*}{ Species } & \multirow[b]{2}{*}{ Common name } & \multirow[b]{2}{*}{$\operatorname{Mix}^{\mathrm{z}}$} & \multirow[b]{2}{*}{ Life cycle ${ }^{y}$} & \multicolumn{2}{|c|}{ Mean blooms $/ \mathrm{m}^{2}( \pm \mathrm{SE})^{\mathrm{x}}$} & \multirow[b]{2}{*}{ Bloom period } & \multirow[b]{2}{*}{ Peak bloom } \\
\hline & & & & 2016 & 2017 & & \\
\hline Chamaecrista fasciculata & Partridge pea & $\begin{array}{l}\text { AP } \\
\text { IT }\end{array}$ & $\mathrm{A}$ & $0.99( \pm 0.21) \mathrm{ab}$ & $30.24( \pm 7.43) \mathrm{a}$ & Late June-Sept. & Mid-July \\
\hline Coreopsis lanceolata & Lanceleaf coreopsis & $\begin{array}{l}\text { AP } \\
\text { IT } \\
\text { P }\end{array}$ & $\mathrm{P}$ & $0.00( \pm 0.00) \mathrm{c}$ & $0.13( \pm 0.032) \mathrm{gh}$ & Late May-mid-June & Mid-June \\
\hline Coreopsis tinctoria & Plains coreopsis & $\begin{array}{l}\text { AP } \\
\text { IT }\end{array}$ & A & $0.74( \pm 0.13) \mathrm{ab}$ & $2.52( \pm 0.93)$ bcdef & Late June-Sept. & Late June/July \\
\hline Echinacea pallida & Pale purple coneflower & $\mathrm{P}$ & $\mathrm{P}$ & $0.00( \pm 0.00) \mathrm{c}$ & $0.00( \pm 0.00) \mathrm{h}$ & NA & NA \\
\hline Echinacea purpurea & Purple coneflower & $\begin{array}{l}\text { AP } \\
\text { IT } \\
\text { P }\end{array}$ & $\mathrm{P}$ & $0.00( \pm 0.00) \mathrm{c}$ & $0.25( \pm 0.049) \mathrm{fg}$ & Late June-Sept. & Mid-Aug. \\
\hline Gaillardia pulchella & Indian blanket & $\begin{array}{l}\text { AP } \\
\text { IT }\end{array}$ & A & $0.41( \pm 0.082) \mathrm{b}$ & $0.53( \pm 0.22)$ defg & Mid-June-Sept. & Sept. \\
\hline Helianthus maximiliani & Maximilian sunflower & $\begin{array}{l}\text { AP } \\
\text { IT } \\
\text { P }\end{array}$ & $\mathrm{P}$ & $0.0084( \pm 0.026) \mathrm{c}$ & $2.64( \pm 0.48) b c$ & Mid-June-late Aug. & Late-July \\
\hline Monarda fistulosa & Wild bergamot & $\begin{array}{l}\text { AP } \\
P\end{array}$ & $\mathrm{P}$ & $0.00( \pm 0.00)$ & $2.02( \pm 0.35) \mathrm{c}$ & Late June--mid-July & Mid-July \\
\hline Monarda punctata & Spotted bee balm & $\mathrm{P}$ & $\mathrm{P}$ & $0.00( \pm 0.00)$ & $7.15( \pm 1.24) \mathrm{ab}$ & Mid-Aug.-Sept. & Sept. \\
\hline Oenothera speciosa & Showy evening primrose & $\mathrm{P}$ & $\mathrm{P}$ & $0.00( \pm 0.00)$ & $1.00( \pm 0.13)$ bcde & Late May-late Aug. & Mid-June \\
\hline Penstemon digitalis & Tall white beardtongue & $\mathrm{P}$ & $\mathrm{P}$ & $0.00( \pm 0.00)$ & $0.00( \pm 0.00) \mathrm{h}$ & NA & NA \\
\hline Pycnanthemum tenuifolium & Narrowleaf mountain mint & $\begin{array}{l}\text { AP } \\
P\end{array}$ & $\mathrm{P}$ & $0.00( \pm 0.00)$ & $0.39( \pm 0.12)$ efgh & Late June-Sept. & Late-July \\
\hline Rudbeckia hirta & Black-eyed Susan & $\begin{array}{l}\text { AP } \\
\text { IT }\end{array}$ & $\mathrm{B}$ & $2.66( \pm 0.56) \mathrm{a}$ & $17.37( \pm 2.99) \mathrm{a}$ & Mid-June-Sept. & Mid-July \\
\hline
\end{tabular}

${ }^{\mathrm{z}} \mathrm{AP}=$ annual perennial mix; IT $=$ imazapic-tolerant mix; $\mathrm{P}=$ perennial-only mix.

${ }^{\mathrm{y}} \mathrm{P}=$ perennial; $\mathrm{A}=$ annual; $\mathrm{B}=$ biennial.

${ }^{x}$ Values within the same column by year are not significantly different when marked by the same letter at the $P \leq 0.05$ level; values are analyzed by the SteelDwass nonparametric test for multiple comparisons. Data are the number of blooming plants per species in 2016 , and the number of blooming stems per species in 2017 in which the number of blooming branches off of the main stem was counted individually, but umbels and composites were considered a single flower. Bloom data are averaged over all plots per block and over three dates in 2016 (13 June, 20 July, and 8 Sept.) and eight dates in 2017 (24 May, 13 June, 28 June, 18 July, 31 July, 14 Aug., 28 Aug., and 27 Sept.).

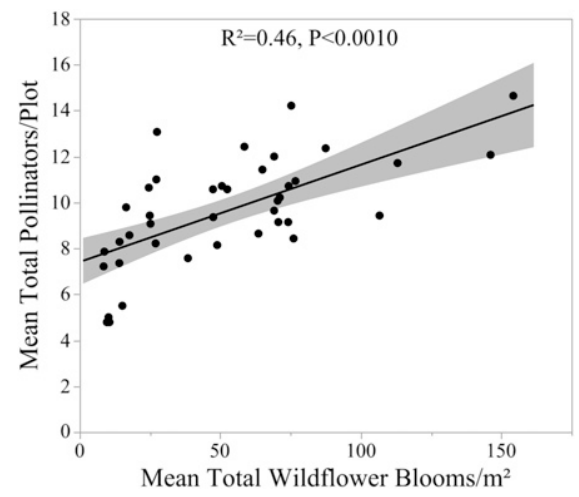

Fig. 3. Linear regression of total pollinators by total wildflower blooms $/ \mathrm{m}^{2}$ in 2017 . Total pollinators include the sum of syrphids, wasps, lepidopterans, honey bees, bumblebees, and "other bee" categories of species.

at very low numbers within all pollinator refuge plantings, with a much higher number of bumblebee and "other bee" species observed relative to all other pollinator groups. The various pollinator groups showed markedly different affinities for different flower species. Blackeyed Susan, maximilian sunflower, and purple coneflower blooms were visited mostly by bees in the "other category"; partridge pea was visited mostly by bumblebees and spotted bee balm was most frequently visited by wasps (Fig. 5).

\section{Discussion}

The overall composition of the PR habitats changed dramatically between years. An initially high weed pressure relative to wildflower growth yielded to relative parity between weed and wildflower cover in year 2 (Figs. 1 and 2). This dynamic of high weed cover in the first year followed by increases in wildflower establishment during the second year is not uncommon, and concurs with studies suggesting that high weed pressure during the first year does not necessarily affect wildflower establishment as long as perennials are able to survive (Love et al., 2016; Skousen and Venable, 2008).

Seedbed preparation proved to be a significant factor affecting weeds and wildflowers, and the effect was still apparent after two growing seasons. The percent cover of wildflowers was higher and that of weeds was lower following a no-till compared with a tilled seedbed preparation in both years of study (Fig. 2). Enhanced establishment culminated in more blooms in the second year in plots with a no-till preparation compared with a tillage preparation. Seedbed preparation differentially affected different species of wildflowers. Indian blanket, purple coneflower, slender mountain mint, and wild bergamot had more blooms in the no-till than the till plots. No species displayed more blooms following tillage than following notillage. Purple coneflower and slender mountain mint seeds are lightweight with a small diameter, whereas wild bergamot and indian blanket are larger, heavier, and chaffier seeds. Smaller seeds may be vulnerable to falling through cracks in the soil to depths at which germination will not occur (Benvenuti et al.,
2001). Seeds prone to wind distribution, such as indian blanket and purple coneflower, might also benefit from shelter by residue on the surface of no-till fields. In fact, winddistributed weeds tend to be more prevalent in no-till than in tilled systems (Derksen et al., 1993; Froud-Williams et al., 1981; Tuesca et al., 2001; Zanin et al., 1997). However, lanceleaf coreopsis seeds also have flattened extensions that may help catch the wind, and we did not observe a seedbed preparation effect on lanceleaf coreopsis bloom counts. Overall, although the effectiveness of no-till preparation relative to tillage contrasts with some previous research (Ahern et al., 1992; Corley, 1991; Corley et al., 1993), it supports the results of a previous study conducted on the same research farm that showed an overall benefit of no-till soil preparation for PR establishment (Angelella and O'Rourke, 2017).

Pollinator refuge establishment was unaffected by herbicides applied after planting. We did not see a difference between herbicide-treated mixes (AP-h, IT, and P-h) and nontreated mixes (AP and P) in wildflower cover, total weed cover, or grass cover. Although postemergent sethoxydim and imazapic have enhanced wildflower establishment in some studies (Beran et al., 1999; Hitchmough et al., 2008; Trowbridge et al., 2017), our work is not the first to report the absence of an effect (Frances, 2008; Love et al., 2016; Washburn and Barnes, 2000). Imazapic phytotoxicity and effectiveness are affected by site-specific factors such as soil 
quality and weather in addition to wildflower species (Bahm and Barnes, 2008; Frances, 2008; Norcini and Aldrich, 2004). In fact, wildflower species reported as tolerant to imazapic, including indian blanket and purple coneflower, have been shown to actually respond negatively to the herbicide with decreased establishment in some cases (Norcini et al., 2003; Washburn and Barnes, 2000), and there have been variations in species tolerances noted among seeds from varied sources (Norcini and Aldrich, 2004). The degree of weed pressure may also predict the effectiveness of herbicide treatments, as wildflower establishment may be increased

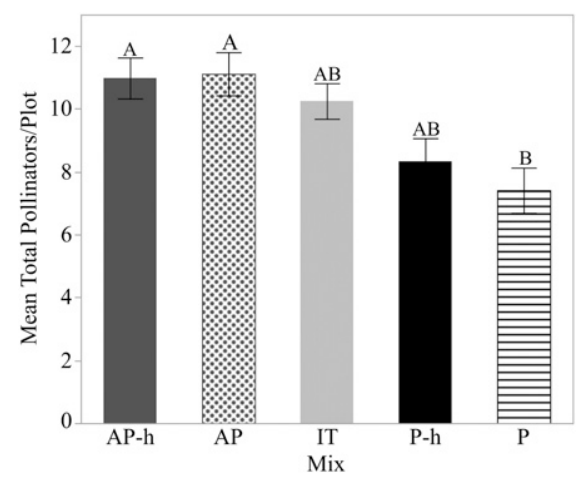

Fig. 4. Total numbers of pollinators in each mixherbicide treatment plot. Data are averaged over seven sampling dates from June through Aug. 2017 and represent pollinators observed during 6-min periods. Means are not significantly different when marked by the same letter, as analyzed by Tukey's honestly significant difference post hoc tests at the $P \leq 0.05$ level. by postemergent imazapic applications in cases of high but not low weed pressure (Beran et al., 1999). Sethoxydim also has a variable record of effectiveness, but in cases where it enhanced establishment, it has been because of alleviating competition with perennial grasses (Hitchmough et al., 2008; Trowbridge et al., 2017). None of the primary weeds in our study were perennial grasses. Moreover, decreasing grass cover with herbicides such as sethoxydim can have detrimental effects on lepidopteran pollinator diversity and abundance (Feber et al., 1996; Russell and Schultz, 2010) because many species of butterflies rely on grasses as larval host plants (Haaland et al., 2011). Considering the possible negative impacts of the herbicides tested and the general progression of all the plots to have less weed coverage in the second year than in the first year of establishment, we do not recommend using herbicides to manage PR habitats after planting wildflower seeds.

Mix composition also proved to be an important factor in wildflower establishment. During the first year of establishment, mixes containing annuals, biennials, and perennials outperformed those containing perennials only: they generated blooms, had higher wildflower percent cover, and had lower percent total weed cover than the perennialonly plots. These results support other recommendations that annual wildflowers can serve as a cover crop to reduce weed establishment (Aldrich, 2002; Elmhirst and Cain, 1990). However, the differences in weed cover among the different flower mixes disappeared in the second year, suggesting long-term establishment might not have been enhanced by weed-suppressive effects from

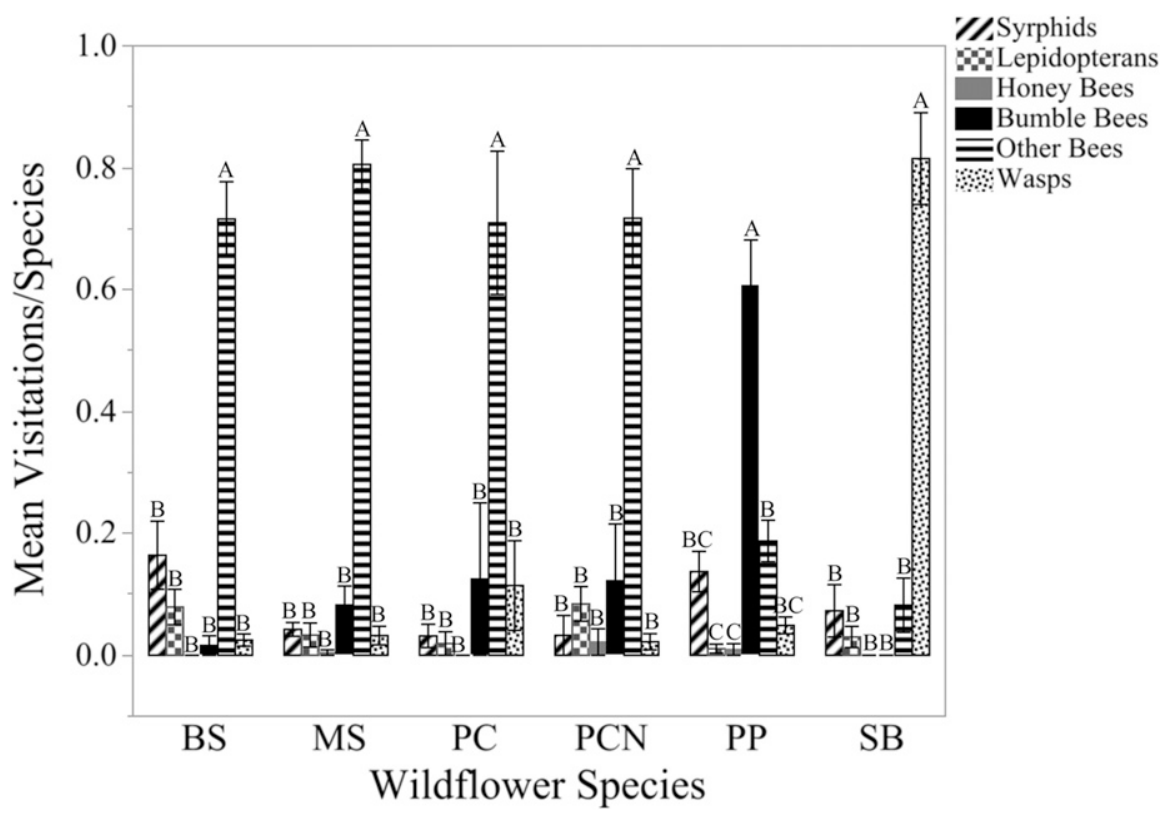

Fig. 5. Proportions of floral visitations by different pollinator groups to individual wildflower species. Data are averaged over three sampling dates in Aug. 2017. BS = black-eyed Susan; MS = maximilian sunflower; $\mathrm{PC}=$ plains coreopsis; $\mathrm{PCN}=$ purple coneflower; $\mathrm{PP}=$ partridge pea; $\mathrm{SB}=$ spotted bee balm. Tukey's honestly significant difference tests were performed to evaluate significant differences among pollinator groups per wildflower species at the $P \leq 0.05$ level. annuals and biennials. The slow establishment of a perennial-only mix could also be a concern if participating landowners want to see blooms and as few weeds as possible in the first year (Junge et al., 2009). However, in future years, we might expect perennials to eventually outcompete with and displace annuals, which could result in floral species richness and evenness declining in the plots containing annuals and biennials (SteffanDewenter and Tscharntke, 2001; Tramer, 1975).

Although all mixes bloomed from late May through September, the different species included in the mixes resulted in varied peak bloom times. In particular, the AP and IT mixes containing annuals/biennials/ perennials peaked in mid-July, whereas the P mix peaked in late August/September. These peaks were largely driven in mixes AP and IT by black-eyed Susan and partridge pea, and by perennial spotted bee balm in mix P. Peak bloom times are important because growers should select mixes that will flower at key times to complement gaps in floral resources provisioned by the surrounding landscape (Carreck et al., 1999; Venturini et al., 2017). The bloom phenology expressed by our annual/biennial/perennial mixes may be more suitable than the perennial-only mix for addressing and mitigating the gap in floral resources in temperate rain-fed agricultural systems.

Pollinator abundance correlated positively with total blooms, evidencing the premise of pollinator refuges (Fig. 3). We also found evidence that floral preferences vary starkly among pollinator groups and that although bumblebees and other native bee species were frequent visitors to the wildflowers we planted, honey bees were very infrequent visitors. Although our observations provide a small snapshot of the entire season, they strongly suggest that wild bees are using PRs and that we can craft refuge bloom phenology and wildflower composition to enhance conservation effectiveness. For example, a recent study in North Dakota found only $13 \%$ of the honey bee floral visitations were to native plant species, whereas $77 \%$ of native bee visitations were to native species (Otto et al., 2017). This demonstrates that incorporating native wildflower species can be important for native pollinator conservation efforts. However, studies conducted in other regions of the United States have reported native wildflower foraging by honey bees comparable with that of wild bees (Morandin and Kremen, 2013; Tuell et al., 2008). Other studies have also noted greater foraging by wild bees relative to honey bees on wildflower strips and seminatural habitats (Balzan et al., 2014; Rollin et al., 2013), whereas honey bees preferred foraging within mass-flowering crops (Rollin et al., 2013). Thus, the scale and spatial configuration of our wildflower plantings may have been more attractive to wild bees than honey bees as well. Moreover, pollinators have also been shown to exhibit differences in general preference between 
annual and perennial plant species (Williams et al., 2015), which supports the idea of mixing functionally diverse plant species in PRs to support pollinator species richness and diversity (Harmon-Threatt and Hendrix, 2015; Isaacs et al., 2009; Morandin et al., 2011; Otto et al., 2017; Williams et al., 2015).

The utility of this research extends beyond farmers and is also applicable to community and home gardens in urban and suburban areas. The physical scale of research plots $(\approx 6 \times 3 \mathrm{~m})$ is akin to the planting space in many residential areas. A recent survey of U.S. consumers who consider themselves "gardeners" found that $50 \%$ of respondents were "consciously purchasing pollinator plants" (Khachatryan and Rihn, 2015). With the growing interest in native habitat and pollinator gardens in the general public, research-based information such as this, regarding site preparation, species mix, and their attractiveness to different groups of pollinators, can help ensure success with school, community, and home gardener efforts to attract diverse pollinators.

Overall, results indicate that seedbed preparation method can have a strong impact on PR establishment, but that selective herbicide or graminicide applications to PRs after planting may be ineffective. We recommend using a no-till seedbed preparation before PR installation in previously cropped areas when possible. Growth and bloom provisions within the first 2 years of establishment favor mixes containing annual, biennial, and perennial forbs over those containing only perennials, but it would be of interest to track the continual successional development relative to bloom coverage and floral diversity over future years.

\section{Literature Cited}

Ahern, J., C. Niedner, and A. Barker. 1992. Roadside wildflower meadows: Summary of benefits and guidelines to successful establishment and management. Transportation Res. Council 1992:46-53.

Aldrich, J.H. 2002. Factors and benefits in the establishment of modest-sized wildflower plantings: A review. Native Plants J. 3:67-86.

Angelella, G.M. and M.E. O'Rourke. 2017. Pollinator habitat establishment after organic and no-till seedbed preparation methods. HortScience 52:1349-1355.

Bahm, M.A. and T.G. Barnes. 2008. Response of native forbs to pre-emergent treatment of imazapic herbicide. East Natl. Grass Symp. 6:98203.

Balzan, M.V., G. Bocci, and A-C. Moonen. 2014. Augmenting flower trait diversity in wildflower strips to optimise the conservation of arthropod functional groups for multiple agroecosystem services. J. Insect Conserv. 18:713-728.

Benvenuti, S., M. Macchia, and S. Miele. 2001. Quantitative analysis of emergence of seedlings from buried weed seeds with increasing soil depth. Weed Sci. 49:528-535.

Beran, D.D., R.E. Gaussoin, and R.A. Masters. 1999. Native wildflower establishment with imidazolinone herbicides. HortScience 34:283286.

Carreck, N., I.H. Williams, and J. Oakley. 1999. Enhancing farmland for insect pollinators using flower mixtures. Asp. Appl. Biol. 54:101-108.

Corley, W. 1991. Seedbed preparation alternatives for establishment of wildflower meadows and beauty spots. Southern Nurserymen's Assn. Res. Conf. Proc. 36. p. 280-281.

Corley, W., T. Murphy, and K. Reynolds. 1993. Weed management options for wildflower meadows and beauty spots. Southern Nurserymen's Assn. Res. Conf. Proc. 38. p. 315-316.

Derksen, D.A., G.P. Lafond, A.G. Thomas, H.A. Loeppky, and C.J. Swanton. 1993. Impact of agronomic practices on weed communities: Tillage systems. Weed Sci. 41:409-417.

Elmhirst, J.F. and N.P. Cain. 1990. Review of roadside wildflower programs and assessment of feasibility in Ontario. Technical Report MAT-90-05. Ontario Ministry of Transport. Res. Dev. Branch, Downsville, Canada.

Feber, R. and H. Smith. 1995. Butterfly conservation on arable farmland, p. 84-97. In: A.S. Pullin (ed.). Ecology and conservation of butterflies. Springer, Dordrecht, The Netherlands.

Feber, R., H. Smith, and D. Macdonald. 1996. The effects on butterfly abundance of the management of uncropped edges of arable fields. J. Appl. Ecol. 33:1191-1205.

Frances, A. 2008. Establishment and management of native wildflowers on Florida roadsides and former pastures. Univ. Florida, Gainesville, FL, PhD Diss.

Froud-Williams, R.J., R.J. Chancellor, and D.S.H. Drennan. 1981. Potential changes in weed floras associated with reduced-cultivation systems for cereal production in temperate regions. Weed Res. 21:99-109.

FSA. 2013. CP42 pollinator habitat: Establishing and supporting diverse pollinator-friendly habitat. Farm Serv. Agency, U.S. Dept. Agr., Washington, D.C.

Fussell, M. and S.A. Corbet. 1992. Flower usage by bumble-bees: A basis for forage plant management. J. Appl. Ecol. 29:451-465.

Haaland, C., R.E. Naisbit, and L.F. Bersier. 2011. Sown wildflower strips for insect conservation: A review. Insect Conserv. Divers. 4:60-80.

Harmon-Threatt, A.N. and S.D. Hendrix. 2015. Prairie restorations and bees: The potential ability of seed mixes to foster native bee communities. Basic Appl. Ecol. 16:64-72.

Hitchmough, J., A. Paraskevopoulou, and N. Dunnett. 2008. Influence of grass suppression and sowing rate on the establishment and persistence of forb dominated urban meadows. Urban Ecosyst. 11:33-44.

Howell, E.A. and V.M. Kline. 1992. The role of competition in the successful establishment of selected prairie species. Proc. 13th N. Amer. Prairie Conf. p. 193-197.

Isaacs, R., J. Tuell, A. Fiedler, M. Gardiner, and D. Landis. 2009. Maximizing arthropod-mediated ecosystem services in agricultural landscapes: The role of native plants. Front. Ecol. Environ. 7:196-203.

Junge, X., K.A. Jacot, A. Bosshard, and P. Lindemann-Matthies. 2009. Swiss people's attitudes towards field margins for biodiversity conservation. J. Natl. Conserv. 17:150-159.

Khachatryan, H. and A. Rihn. 2015. Are consumers interested in ornamental plants that benefit pollinator insects? Food Resource Econ. Dept., Univ. Florida. Inst. Food Agr. Sci. FE 997.

Love, S.L., P.J. Hutchinson, and W.J. Price. 2016. Managing weeds during wildflower meadow establishment in the arid intermountain west: Efficacy of a grass-first strategy for sites with heavy annual weed pressure. Native Plants J. 17:216-229.
Lulow, M.E. 2006. Invasion by non-native annual grasses: The importance of species biomass, composition, and time among California native grasses of the Central Valley. Restor. Ecol. 14:616-626.

Martin, L.C. 1986. The wildflower meadow book. East Woods Press, Charlotte, NC.

Menz, M.H., R.D. Phillips, R. Winfree, C. Kremen, M.A. Aizen, S.D. Johnson, and K.W. Dixon. 2011. Reconnecting plants and pollinators: Challenges in the restoration of pollination mutualisms. Trends Plant Sci. 16: 4-12.

Morandin, L., R. Long, C. Pease, and C. Kremen. 2011. Hedgerows enhance beneficial insects on farms in California's Central Valley. Calif. Agr. 65:197-201.

Morandin, L.A. and C. Kremen. 2013. Bee preference for native versus exotic plants in restored agricultural hedgerows. Restor. Ecol. 21:2632.

Norcini, J.G. and J.H. Aldrich. 2004. Establishment of native wildflower plantings by seed. Univ. Flor. Inst. Food Agr. Sci. ENH 968.

Norcini, J.G., J.H. Aldrich, and F.G. Martin. 2003. Tolerance of native wildflower seedlings to imazapic. J. Environ. Hort. 21:68-72.

NRCS. 2007. Conservation cover (327a): Virginia conservation practice VA job sheet. U.S. Dept. Agr., Washington, D.C.

NRCS. 2012. Conservation cover (327): Maryland herbaceous plantings for pollinator habitat. U.S. Dept. Agr., Washington, D.C.

Otto, C.R., S. O’Dell, R. Bryant, N. Euliss, R. Bush, and M.D. Smart. 2017. Using publicly available data to quantify plant-pollinator interactions and evaluate conservation seeding mixes in the Northern Great Plains. Environ. Entomol. 46:565-578.

Perry, L.P. 2005. Successful wildflower meadows. Univ. Vermont Ext. Bul. OH 84.

Rollin, O., V. Bretagnolle, A. Decourtye, J. Aptel, N. Michel, B.E. Vaissière, and M. Henry. 2013. Differences of floral resource use between honey bees and wild bees in an intensive farming system. Agr. Ecosyst. Environ. 179:78-86.

Russell, C. and C.B. Schultz. 2010. Effects of grass-specific herbicides on butterflies: An experimental investigation to advance conservation efforts. J. Insect Conserv. 14:53-63.

Skousen, J.G. and C. Venable. 2008. Establishing native plants on newly-constructed and olderreclaimed sites along West Virginia highways. Land Degrad. Dev. 19:388-396.

Steffan-Dewenter, I. and T. Tscharntke. 2001. Succession of bee communities on fallows. Ecography 24:83-93.

Tramer, E.J. 1975. The regulation of plant species diversity on an early successional old field. Ecology 56:905-914.

Trowbridge, C.C., A. Stanley, T.N. Kaye, P.W. Dunwiddie, and J.L. Williams. 2017. Longterm effects of prairie restoration on plant community structure and native population dynamics. Restor. Ecol. 25:559-568.

Tuell, J.K., A.K. Fiedler, D. Landis, and R. Isaacs. 2008. Visitation by wild and managed bees (Hymenoptera: Apoidea) to eastern US native plants for use in conservation programs. Environ. Entomol. 37:707-718.

Tuesca, D., E. Puricelli, and J. Papa. 2001. A longterm study of weed flora shifts in different tillage systems. Weed Res. 41:369-382.

Vaughan, M., E. Mäder, J. Guisse, J. GoldenetzDollar, B. Borders, K. Gill, R. Winfree, and M. MacLeod. 2013. Conservation cover (327) for pollinators: New Jersey installation guide and 
job sheet. Xerces Soc. Invertebrate Conserv., Portland, OR.

Vaughan, M. and M. Skinner. 2008. Using farm bill programs for pollinator conservation. U.S. Dept. Agr. Natl. Resource Conserv. Serv. National Plant Data Center. <http:// www.xerces.org/wp-content/uploads/2008/ 11/using_farm_bill_programs_xerces_society.pdf $>$.

Vaughan, M. and M. Skinner. 2015. Using 2014 Farm Bill programs for pollinator conservation. U.S. Dept. Agr. Biol. Tech. Note 78.
Venturini, E.M., F.A. Drummond, A.K. Hoshide, A.C. Dibble, and L.B. Stack. 2017. Pollination reservoirs for wild bee habitat enhancement in cropping systems: A review. Agroecol. Sustain. Food Syst. 41:101-142.

Washburn, B.E. and T.G. Barnes. 2000. Native warm-season grass and forb establishment using imazapic and 2, 4-D. Native Plants J. 1:61-69.

Williams, N.M., K.L. Ward, N. Pope, R. Isaacs, J. Wilson, E.A. May, J. Ellis, J. Daniels, A. Pence, and K. Ullmann. 2015. Native wildflower plantings support wild bee abundance and diversity in agricultural landscapes across the United States. Ecol. Appl. 25:21192131.

Wilson, J.W. 1992. Landscaping with wildflowers: An environmental approach to gardening. Houghton Mifflin Harcourt Publishing Co., Boston, MA.

Zanin, G., S. Otto, L. Riello, and M. Borin. 1997. Ecological interpretation of weed flora dynamics under different tillage systems. Agr. Ecosyst. Environ. 66:177-188. 

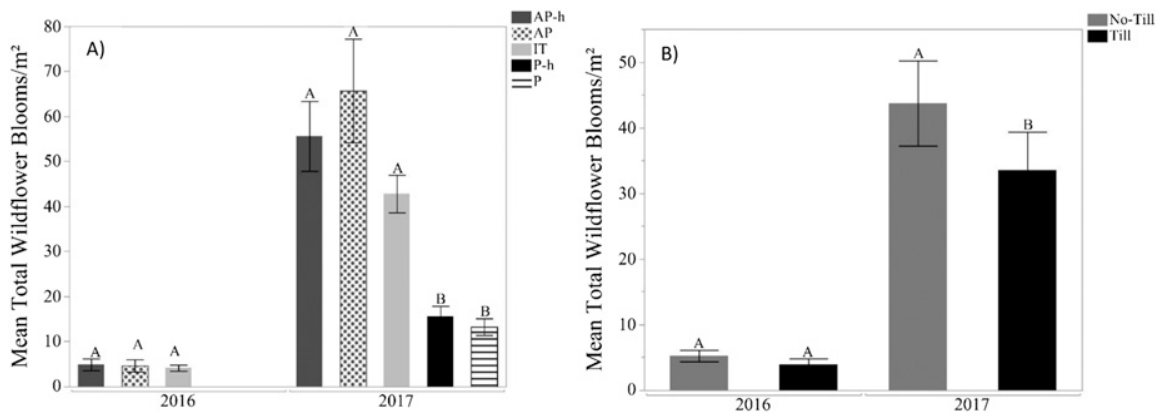

Supplemental Fig. 1. Mean total wildflower blooms in 2016 and 2017 by (A) mix and (B) seedbed preparation. Annual and perennial mix (mix AP-h) includes nine species of annual and perennial wildflowers and was treated with a sethoxydim herbicide, mix AP is the same wildflower mix without herbicide, an imazapic-tolerant mix contains a subset of seven AP wildflower species and was treated with imazapic herbicide, perennial-only mix (mix P-h) contains nine perennial wildflowers and was treated with sethoxydim herbicide, and mix P is the same wildflower mix without herbicide. Pairwise means comparisons were tested across mixes and within each year by Tukey's honestly significant difference post hoc analysis, and between no-till and till methods within each year with Student's $t$ tests. Means within the same year are not significantly different when marked by the same letter at the $P \leq 0.05$ level.

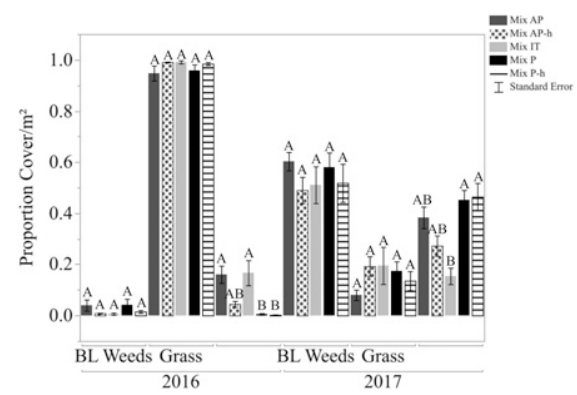

Supplemental Fig. 2. Proportions of broadleaf weed, grass weed, and wildflower cover in different mix-herbicide treatments. Vegetative cover sampled on 8 Sept. 2016 and 11 Sept. 2017. Pairwise means comparisons tested across mixes and within year by the SteelDwass nonparametric post hoc analysis in 2016 and by Tukey's honestly significant difference analysis in 2017. Grass cover in 2017 was $\log +1$ transformed before analysis. Means within the same year are not significantly different when marked by the same letter at the $P \leq 0.05$ level. 
Supplemental Table 1. Species and seeding rates of pollinator refuge plantings.

\begin{tabular}{|c|c|c|c|c|c|c|c|}
\hline$\overline{M i x}$ & Species & Common name & Family & Pollinator value $^{z}$ & Life cycle ${ }^{y}$ & Seeds $/ g^{z}$ & $\mathrm{PLS} / \mathrm{m}^{2}$ \\
\hline$\overline{\mathrm{AP}}, \mathrm{IT}$ & Chamaecrista fasciculata (Michx.) Greenew & Partridge pea & Fabaceae & High & A & 143 & 32 \\
\hline AP, IT & Gaillardia pulchella Foug." & Indian blanket & Asteraceae & High & A & 525 & 48 \\
\hline AP, IT & Rudbeckia hirta L." & Black-eyed Susan & Asteraceae & Low & B & 3,473 & 75 \\
\hline AP, IT, P & Echinacea purpurea (L.) Moench ${ }^{\mathrm{w}}$ & Purple coneflower & Asteraceae & High & $\mathrm{P}$ & 234 & $48,95^{\mathrm{v}}$ \\
\hline AP, IT, P & Helianthus maximiliani Schrad.w & Maximilian sunflower & Asteraceae & High & $\mathrm{P}$ & 433 & $48,95^{\mathrm{v}}$ \\
\hline $\mathrm{AP}, \mathrm{P}$ & Monarda fistulosa L." & Wild bergamot & Lamiaceae & High & $\mathrm{P}$ & 2,805 & 30 \\
\hline $\mathrm{P}$ & Monarda punctata L." & Spotted bee balm & Lamiaceae & High & $\mathrm{P}$ & 3,245 & 75 \\
\hline $\mathrm{P}$ & Oenothera speciosa Nutt. $^{\mathrm{w}}$ & Showy evening primrose & Onagraceae & Moderate & $\mathrm{P}$ & 6,700 & 75 \\
\hline $\mathrm{P}$ & Penstemon digitalis Nutt. ex Sims ${ }^{\mathrm{u}}$ & Tall white beardtongue & Plantaginaceae & High & $\mathrm{P}$ & 882 & 48 \\
\hline
\end{tabular}

${ }^{\mathrm{z}}$ B. Glennon, personal communication, U.S. Department of Agriculture's Natural Resources Conservation Service, Wildlife Seed Mix Calculator V3.2_May2016. xlsx.

${ }^{\mathrm{y}} \mathrm{P}=$ perennial; $\mathrm{A}=$ annual; $\mathrm{B}=$ biennial.

${ }^{\mathrm{x}}$ Pure live seed.

${ }^{\text {w}}$ Purchased from Ernst Conservation Seeds (Meadowville, PA).

${ }^{\mathrm{v}}$ The IT mix only was planted at higher density.

"Purchased from Roundstone Native Seed Company (Upton, KY).

$\mathrm{AP}=$ annual perennial mix; IT = imazapic-tolerant mix; $\mathrm{P}=$ perennial-only mix. 


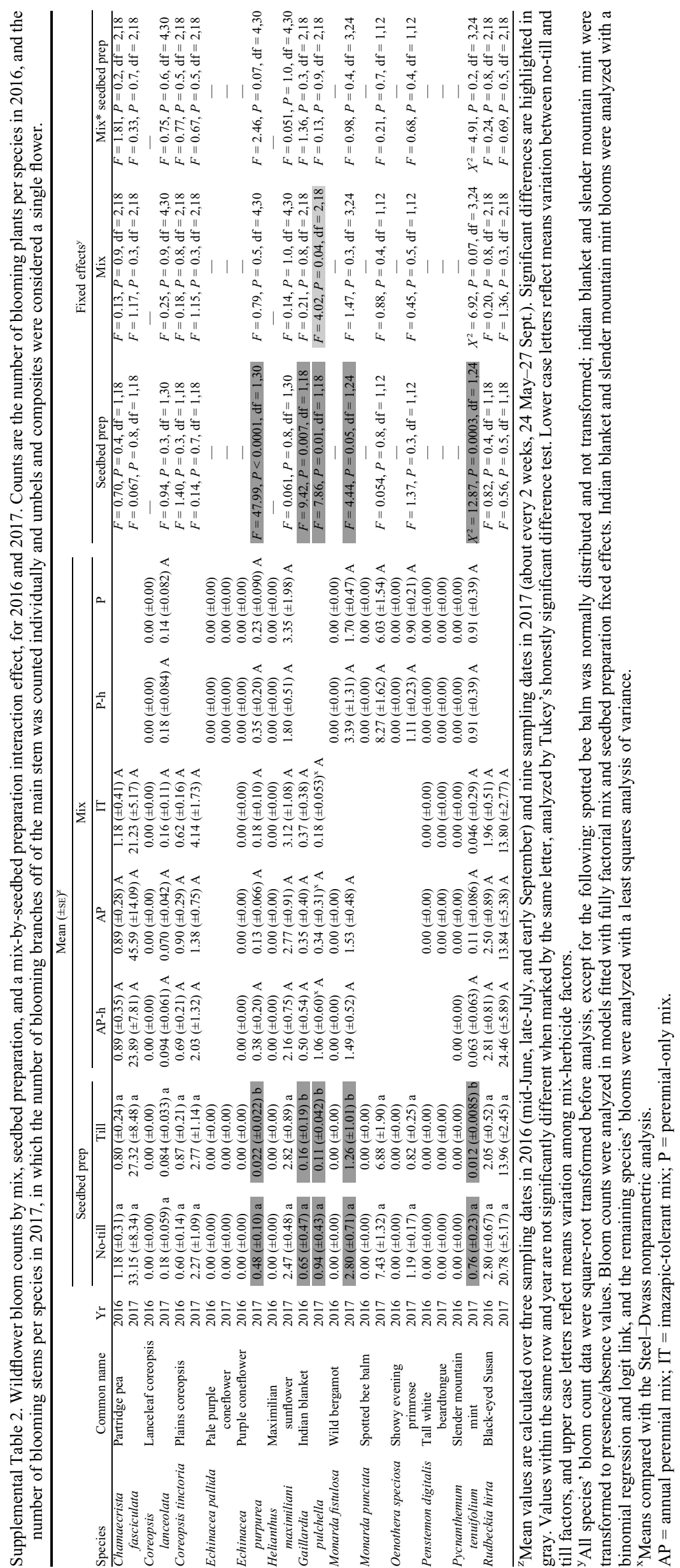

